\title{
Prader-Willi syndrome: a review of clinical, genetic, and endocrine findings
}

\author{
M. A. Angulo ${ }^{1}$ M. G. Butler ${ }^{2}$ M. E. Cataletto ${ }^{3}$
}

Received: 17 March 2015 / Accepted: 11 May 2015 / Published online: 11 June 2015

(C) The Author(s) 2015. This article is published with open access at Springerlink.com

\begin{abstract}
Introduction Prader-Willi syndrome (PWS) is a multisystemic complex genetic disorder caused by lack of expression of genes on the paternally inherited chromosome 15q11.2-q13 region. There are three main genetic subtypes in PWS: paternal 15q11-q13 deletion (65-75\% of cases), maternal uniparental disomy 15 (20-30\% of cases), and imprinting defect (1-3\%). DNA methylation analysis is the only technique that will diagnose PWS in all three molecular genetic classes and differentiate PWS from Angelman syndrome. Clinical manifestations change with age with hypotonia and a poor suck resulting in failure to thrive during infancy. As the individual ages, other features such as short stature, food seeking with excessive weight gain, developmental delay, cognitive disability and behavioral problems become evident. The phenotype is likely due to hypothalamic dysfunction, which is responsible for hyperphagia, temperature instability, high pain threshold, hypersomnia and multiple endocrine abnormalities including growth hormone and thyroid-stimulating hormone
\end{abstract}

M. A. Angulo

moris.angulo@gmail.com; mangulo@winthrop.org

M. G. Butler

mbutler4@kumc.edu

M. E. Cataletto

mcataletto@winthrop.org

1 Department of Pediatrics, Winthrop University Hospital, 101 Mineola Blvd, 2nd Floor, Mineola, NY 11501, USA

2 Department of Psychiatry and Behavioral Sciences and Pediatrics, University of Kansas Medical Center, 3901 Rainbow Blvd, MS 4015, Kansas City, KS 66160, USA

3 Department of Pediatrics, Winthrop University Hospital, 120 Mineola Blvd, Suite210, Mineola, NY 11501, USA deficiencies, hypogonadism and central adrenal insufficiency. Obesity and its complications are the major causes of morbidity and mortality in PWS.

Methods An extensive review of the literature was performed and interpreted within the context of clinical practice and frequently asked questions from referring physicians and families to include the current status of the cause and diagnosis of the clinical, genetics and endocrine findings in PWS.

Conclusions Updated information regarding the early diagnosis and management of individuals with Prader-Willi syndrome is important for all physicians and will be helpful in anticipating and managing or modifying complications associated with this rare obesity-related disorder.

Keywords Prader-Willi syndrome - Obesity · Chromosome 15 abnormalities - Genomic imprinting . Endocrine disturbances $\cdot$ Short stature $\cdot$ Hypogonadism

\section{Introduction}

Prader-Willi syndrome (PWS) was first described by Prader et al. in 1956 [1] and now recognized as a genomic imprinting disorder whereby differential expression of genes depending on the parent of origin contributes to the imprinting process. Errors in genomic imprinting, which occurs during both male and female gametogenesis are causative for PWS and include the loss of expression of paternal genes, which are normally active and located in the chromosome 15q11-q13 region [2-6]. Conversely, a loss of expression of the preferentially maternally expressed UBE3A gene in this region leads to Angelman syndrome (AS), an entirely different clinical disorder [7, 8]. About two-thirds of individuals with PWS have a de novo 
Fig. 1 a Obesity, almond shape eyes, down-turned mouth and straight borders of inner legs. b Straight borders of ulnar side of hands and scares from skin picking. c Active and healing skin lesions on scalp
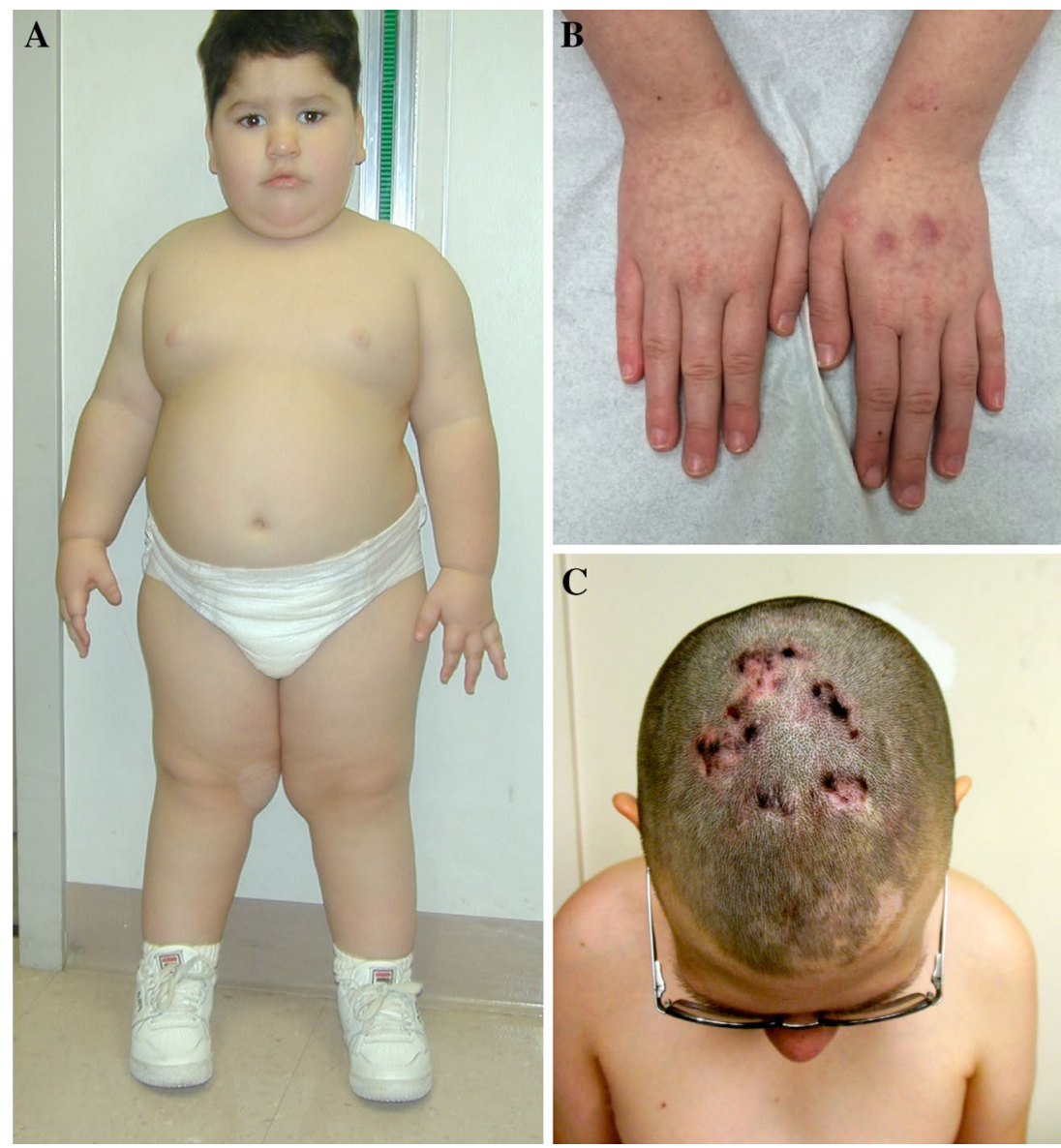

paternally inherited deletion of the chromosome 15q11-q13 region. The remaining individuals have maternal disomy 15 (both chromosome $15 \mathrm{~s}$ received from the mother with no paternal chromosome 15 present) in about $25 \%$ [9] of cases or have defects in the genomic imprinting center due to microdeletions or epimutations found in fewer than $3 \%$ of cases [2, 4, 10, 11]. On very rare occasions, chromosomal translocations or rearrangements of the $15 q 11-q 13$ region are reported [2, 12-17].

With an estimated prevalence of 1/10,000-1/30,000, PWS is the most common syndromal cause of life-threatening obesity and the first recognized disorder related to genomic imprinting in humans [9, 18]. Affected infants uniformly have significant hypotonia, feeding difficulties, and failure to thrive (FTT), followed in later infancy or early childhood by excessive appetite with gradual development of obesity, short stature and/or decreased growth velocity, intellectual disabilities (average IQ of 65), and behavioral problems (e.g., temper tantrums, outburst, and skin picking) [3, 13]. Hypothalamic dysfunction has been implicated in many manifestations of this syndrome including hyperphagia, temperature instability, high pain threshold, sleep-disordered breathing, and multiple endocrine abnormalities $[3,5,6]$.
This review summarizes clinical manifestations, genetics and genetic testing, sleep-disordered breathing, and screening with management of endocrine abnormalities associated with PWS.

\section{Clinical manifestations and characteristic features of PWS}

Severe hypotonia is consistently observed at birth and during the neonatal period [3]; therefore, PWS should be considered in all cases of unexplained neonatal hypotonia. Other features noted during the neonatal period include lethargy, feeding difficulties, thick saliva, and increased head/chest circumference ratio, small genitalia in both males and females with frequent cryptorchidism in males. In older untreated children with obesity, developmental delay, short stature and/or decreased growth velocity, and dysmorphic features are found including a narrow bifrontal diameter, almond-shaped palpebral fissures, a thin upper lip with a down-turned mouth, small hands and feet, straight borders of ulnar side of hands and of inner legs (Fig. 1) [3]. Clinical diagnostic criteria were established by consensus in 1993 [19]. Subsequently, definitive molecular genetic 
Table 1 Suggested new criteria to prompt DNA testing for PraderWilli syndrome (PWS)

\begin{tabular}{ll}
\hline Age at assessment & Features to prompt DNA testing for \\
\hline BWS & 1. Severe hypotonia and poor suck \\
2-6 years & 1. Hypotonia with history of poor suck \\
2. Global developmental delay & 3. Short stature and/or decreased growth \\
velocity & 4. Hypogenitalism/hypogonadism \\
1. History of hypotonia with poor suck \\
2. Global developmental delay \\
3. Excessive eating with central obesity, \\
if uncontrolled \\
4. Hypogenitalism/hypogonadism \\
1. Cognitive impairment; usually mild \\
intellectual disability \\
2. Excessive eating (hyperphagia; obses- \\
sion with food) with central obesity, if \\
uncontrolled \\
3. Hypogonadism and/or typical \\
behavior problems (including temper \\
tantrums and obsessive-compulsive \\
features) \\
4. Short stature; small hands and feet \\
adulthood
\end{tabular}

Adapted from Gunay-Aygun et al. [20]

testing became available for laboratory diagnosis of PWS. These clinical criteria were later modified to help define people for whom further diagnostic testing is indicated and at different ages (Table 1) [20]. DNA methylation analysis is the most efficient way to confirm the diagnosis if PWS is suspected clinically but will not identify the genetic subtype [3, 21, 22].

Classically, two nutritional developmental phases have been described in PWS: Phase 1, in which the individual exhibits poor feeding and hypotonia, often with FTT; and Phase 2 , which is characterized by "hyperphagia leading to obesity" $[3,6,13]$ but recently a total of seven different nutritional phases, with five main phases and sub-phases in Phases 1 and 2 have been identified [23]. Increase in appetite is seen in Phase $2 b$ at age $4.5-8$ years, whereas the classical hyperphagia becomes evident during Phase 3 (Table 2).

The last two decades have seen significant increases in the understanding of mechanisms controlling appetitive behavior, body composition, and energy expenditure. Many regions throughout the central nervous system play critical roles in these processes but the hypothalamus, in particular, receives and orchestrates a variety of signals to bring about coordinated changes in energy balance. Ghrelin, a 28 amino acid peptide produced in the stomach, is the only peripheral hormone to transmit satiety signal. Plasma ghrelin level in obese PWS individuals is higher than any other form of obesity and considered as one of the contributing factors for their obesity $[24,25]$. A somatostatin analog infusion in 4 adults [26] and long-acting octreotide infusion in 8 adolescents with PWS effectively suppressed ghrelin elevation before meals but not the appetite [27]. Circulating ghrelin levels are elevated in young children with PWS long before the onset of hyperphagia, especially during the early phase of poor appetite and feeding [28]. Based on these studies, it seems unlikely that high ghrelin levels alone are directly responsible for the switch to the hyperphagic nutritional phases in PWS.

Diabetes mellitus type 2 (T2 DM), a metabolic disorder characterized by hyperglycemia in the context of insulin resistance has been reported in $25 \%$ of adult PWS population [29]. Those individuals with T2 DM had a higher past maximum body weight and a greater likelihood of positive family history. Fasting insulin concentrations and homeostasis model assessment insulin resistance index however, are lower in PWS children than in obese control $(P<0.05)$ and similar to lean control subjects [30]. Not surprisingly, a study of 74 children with PWS at a median age of 10.2 years showed that none had T2 DM and only $4 \%$ had impaired oral glucose tolerance by OGTT [31]. T2 DM should be managed accordingly with special attention to those children on GH treatment with higher risk for insulin resistance. Periodic fasting serum glucose and insulin levels are recommended before and after initiation of GH treatment.

\section{Genetics}

Errors in genomic imprinting are the cause of PWS. It is considered as a phenomenon of epigenetics and modified dependent on the parental sex contributing the genes where epigenetic changes can control expression or gene activity without changing the DNA structure or base pair sequence [32]. The epigenetic process is reversible and occurs during both male and female gametogenesis. The 'on or off' activity of gene expression or regulation is usually through DNA methylation at specific bases (e.g., cytosine). Nearly 150 genes in humans are thought to be imprinted and contain CpG-rich differentially methylated DNA regions that correlate with gene allele activity [18]; several located on chromosome 15.

The genes and transcripts located in the 15q11-q13 region can be grouped into four areas delineated by three common deletion breakpoints (Fig. 2): (1) A group of nonimprinted genes, GCP5, CYFIP1, NIPA1, and NIPA2, are located between proximal 15q11-q13 breakpoints BP1 and BP2 and other genes between 15q11-q13 breakpoints BP2 and BP3 (e.g., $P$ gene) are also expressed equally from the 
Table 2 Clinical characteristics of the nutritional phases seen in Prader-Willi syndrome

\begin{tabular}{ll}
\hline Phase 0 & Decreased fetal movements and lower birth weight than \\
& sibs \\
Phase 1a & Hypotonia with difficulty feeding (0-9 months) \\
& Needs assistance with feeding either through feeding \\
& tubes [nasal/oral gastric tube or gastrostomy tube] or \\
& orally with special, widened nipples \\
& Decreased appetite \\
Phase 1b & No difficulty feeding and normal growth (9-25 months) \\
Phase 2a & Weight increasing without appetite increase (2.1-4.5 \\
& years) \\
& Will become obese if given the recommended daily \\
& allowance [RDA] for calories \\
Typically needs to be restricted to $60-80 \%$ of RDA to \\
prevent obesity \\
Phase 2b \\
Weight and appetite are increased (4.5-8 years) \\
Will become obese if allowed to eat what they want \\
Hyperphagic, rarely feels full (8 years-adulthood) \\
Constantly thinking about food with temper tantrums \\
related to food \\
Appetite is no longer insatiable (adulthood) \\
Improvement in control of appetite and temper tantrums \\
Most adults have not gone into this phase and maybe \\
some (most?) never will
\end{tabular}

Adapted from Miller et al. [23] paternal and maternal alleles; (2) imprinted genes (paternal expression only) include $M K R N 3, M A G E L 2, N D N$, and the bicistronic SNURF-SNRPN gene; (3) the preferentially maternally expressed genes UBE3A and ATP10A (with disturbances in $U B E 3 A$ causing Angelman syndrome); and (4) non-imprinted genes show evidence of paternally biased expression (e.g., GABRB3) [2, 33, 34]. The bicistronic $S N U R F-S N R P N$ gene in the $15 \mathrm{q} 11-\mathrm{q} 13$ region is involved in mRNA splicing in the brain encoded by exons 4 to 10 . Exons 1 through 3 of this complex gene encode a separate protein, which is involved in the genomic imprinting process [2]. Multiple copies of the so-called C/D box small nucleolar RNAs (snoRNAs) or SNORDs (SNORD64, SNORD107, SNORD109A, SNORD115, and SNORD116) are also located in this region and key in the development of PWS with involvement in RNA processing. SNORDs are encoded by a large extended transcript from the complex $S N U R F-S N R P N$ gene locus and not translated into protein [35-38].

Other protein coding genes in the $15 \mathrm{q} 11-\mathrm{q} 13$ region include MKRN3, MAGEL2, and NDN which are imprinted and paternally expressed. They are located proximally to the imprinting center (IC) located at the SNRPN-SNURF gene complex locus and involved in neural development and brain function $[2,4,5]$. The MAGEL2 gene encodes a protein found in the hypothalamus and other brain areas and recently have been reported to be involved in autism spectrum disorder [39]. It appears to function in circadian rhythm, brain structure development, and human reproduction and infertility. The MKRN3 gene generates specific proteins (makorins), which are abundantly expressed in the brain and involved with hormone regulation and precocious puberty [40]. The $N D N$ gene is thought to play a role in axonal outgrowth and expressed in brain regions possibly involved in regulating respiration rate. Two additional genes (PWRN1, PWRN2) are also located close to the NDN gene with the PWRNI as a possible novel alternative start site for the $S N U R F-S N R P N$ gene complex activity [41]. The UBE3A and ATP10C genes are imprinted, maternally expressed, and paternally silent. The UBE3A gene is involved in Angelman syndrome. Several transcripts in the 15q11-q13 region are read in an anti-sense direction and complementary to DNA sequences of other genes in a reverse direction, including the $U B E 3 A$ anti-sense transcript. Other genes found in the distal non-imprinted area of the 15q11-q13 region include the gamma aminobutyric acid (GABA) receptor subunits (i.e., GABRB3, GABRG3, GABRA5), the P locus for oculocutaneous albinism type 2 (OCA2) and HERC2 [2, 4, 5]. The HERC2 gene encodes an ubiquitin ligase protein, which is expressed in high levels in the fetus and lower expression in the adult brain, testis, ovary, and muscle tissue [10, 42].

Studies have shown that the GABA receptor subunit genes (i.e., GABRB3, GABRA5) are expressed unequally 


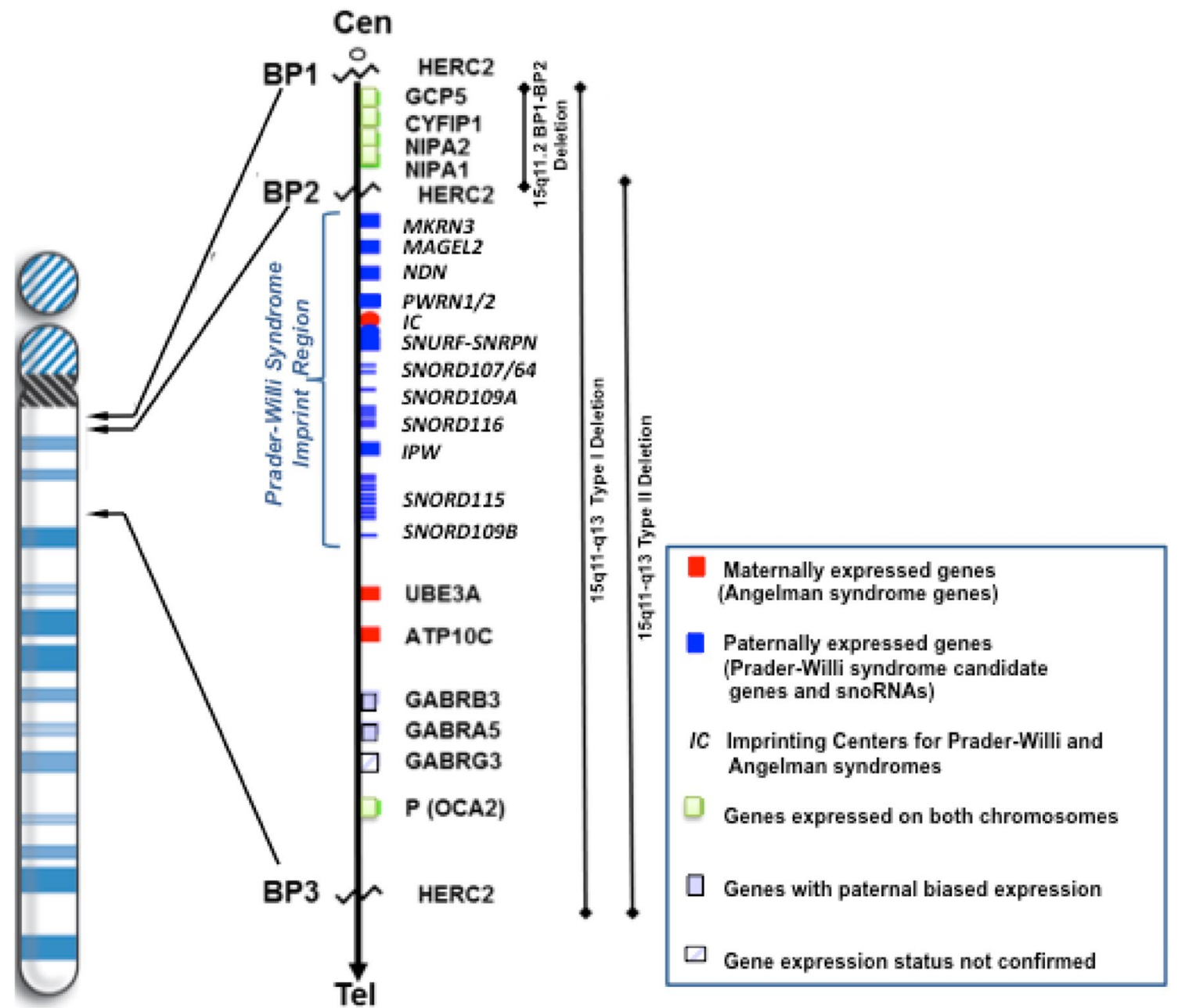

Fig. 2 High resolution chromosome 15 ideogram and locations of breakpoints BP1 and BP2 [at 15q11.2 band] and BP3 [at 15q13.1 band] are shown with position of the four non-imprinted genes between breakpoints $\mathrm{BP} 1$ and $\mathrm{BP} 2$ and those imprinted and non-

between the paternal and maternal alleles thereby indicating altered allelic expression. Loss of the paternal allele for these genes produces lower than the expected $50 \%$ expression which indicates paternal bias with more expression from the paternal allele than the maternal allele using lymphoblasts carrying different chromosome 15 defects (e.g., deletions, uniparental disomy) [33, 34]. GABA is an important neurotransmitter with inhibitory capability at the brain level. Thus, alterations in gene expression may be associated with appetite, visual perception, and memory changes. The $\mathrm{P}$ gene is involved with pigmentary status in individuals with PWS or Angelman syndrome having the typical chromosome $15 \mathrm{q}$ deletion. This oculocutaneous albinism type 2 gene when disturbed in individuals with PWS or Angelman syndrome having the typical 15q11-q13 deletion will show hypopigmentation $[2,4,5,43]$. imprinted genes between breakpoints BP2 and BP3. Three recognized deletion subtypes and their locations in the 15q11-q13 region (i.e., 15q11.2 BP1-BP2; typical 15q11-q13 type I; typical 15q11-q13 type II) are represented

\section{Genetic subtypes and diagnostic testing for Prader-Willi syndrome}

There are three main genetic mechanisms that result in PWS: paternal 15q11-q13 deletion, maternal uniparental disomy (UPD) 15, and imprinting defects (ID).

\section{Paternal deletion}

Two proximal chromosome 15q11-q13 breakpoints (BP1 and BP2) and a distal breakpoint (BP3) appear to predispose to the typical deletions seen in PWS $(65-75 \%$ of cases) and Angelman syndrome [2, 4, 5]. The most common typical deletions are of two classes, Type I and Type II (Fig. 2). The Type I deletion is larger and involves the proximal breakpoint BP1 which is nearest to the chromosome 
15 centromere while the smaller Type II deletion involves the other proximal breakpoint BP2. The third common breakpoint (BP3) is located distally in this chromosome region and is involved in both typical deletion types [44]. Four genes are located in the genomic area between proximal breakpoints BP1 and BP2 including GCP5, CYFIP1, NIPA1, and NIPA2. These genes are overly expressed in the brain and when mutated (e.g., NIPAI) can lead to spastic paraplegia and brain disturbances [45, 46]. PWS individuals with the smaller Type II deletion have these four genes intact. Individuals without PWS are reported with behavioral and autistic findings when only a deletion is present involving the region between breakpoints $\mathrm{BP} 1$ and $\mathrm{BP} 2$, the chromosome 15q11.2 BP1-BP2 microdeletion (BurnsideButler) syndrome [47-49].

PWS individuals with the larger Type I deletion have been reported to be more prone to obsessive compulsion and self-injury (skin picking) in addition to visual processing deficits and lower measures of academic performance than those PWS individuals with the smaller Type II deletion having the four genes intact between proximal breakpoints BP1 and BP2 [50, 51]. Other deletions that are not typical and vary in size involving areas of the 15q11-q13 region are reported in about $5 \%$ of PWS individuals $[2,4$, $5,16]$. These individuals are often more atypical in their clinical presentation [15].

The smallest genetic defects in the 15q11-q13 region often include microdeletions of the paternally expressed non-coding snoRNAs such as SNORD115 and SNORD116 [15, 35-37]. Studies in mice containing disturbances of SNORD116 equivalent transcripts exhibit hyperphagia and growth failure, which are common features in PWS. In addition, research supports that SNORD115 regulates alternative splicing of the human serotonin 5-HT2C receptor providing an altered receptor form leading to excessive eating behavior [38], a cardinal feature seen in PWS.

\section{Maternal uniparental disomy (UPD) 15}

The second most frequent genetic finding in PWS is due to an error in meiosis, most common when two maternal chromosome $15 \mathrm{~s}$ are contributed in the egg and fertilized by a normal sperm. This leads to 47 chromosomes in the fetus causing trisomy 15 . Trisomy 15 is a relatively common cause of early miscarriages in humans. If a trisomy 15-rescue event occurs, then one of the chromosome $15 \mathrm{~s}$ will be lost from the trisomic cell leading to a normal 46 chromosome count with continuation of the pregnancy. If the paternal chromosome 15 is lost then the cell will have two maternal chromosomes $15 \mathrm{~s}$. The fetus will survive with two maternal chromosomes 15 (UPD) with the clinical picture of PWS but normal cytogenetic findings at the time of delivery [52].
Maternal uniparental disomy (UPD) 15 in PWS can be of three types: (1) heterodisomy, as a result of non-disjunction of homologous chromosome $15 \mathrm{~s}$ in meiosis I, thus the baby inherits each of the mother's two chromosome $15 \mathrm{~s}$; (2) isodisomy, as a result of non-disjunction in meiosis II with two identical chromosome $15 \mathrm{~s}$ inherited from the mother; and (3) segmental form occurs when regions of chromosome 15 have identical genetic information as a result of crossing-over events and non-disjunction in meiosis I or possibly by a somatic chromosome recombination in early pregnancy. The type of disomic event may impact on the pregnancy and clinical outcome of the fetus. Most PWS subjects with maternal disomy 15 have the heterodisomic form [4, 5, 53].

Extra attention however, should be given to PWS individuals with maternal disomy 15 if the isodisomic or segmental type is present by examining for additional genetic disorders due to mutant recessive genes carried on the maternal chromosome 15q. Special genetic testings such as high-resolution DNA microarrays with SNP probes are recommended to assist in identifying the disomic status. As in other non-disjunction cases, the risk of maternal disomy 15 increases with maternal age. Those PWS individuals with maternal disomy 15 often have delayed diagnosis, higher verbal IQ scores with greater attention, and factual knowledge and better social reasoning skills than those with the typical Type I or Type II deletions involving the 15q11-q13 region but are more prone to increased episodes of psychosis and autistic behaviors $[45,50,51]$.

\section{Imprinting defects (ID)}

Most individuals with PWS are due to sporadic causes but in some families the defective error is from an epimutation or incomplete processing of the imprint in germ cell meiosis from the father or from a microdeletion of the DNA imprinting center $(1-3 \%)$. The microdeletion defect has been reported in about $15 \%$ of individuals with PWS due to ID [11], although more recent studies indicate a possible higher rate for microdeletions in the imprinting center [54]. This microdeletion can be contributed by the paternal grandmother to the father and lead to birth of another child with PWS. The risk in this situation is $50 \%$.

\section{Diagnostic genetic testing}

DNA methylation provides a powerful tool to assess paternal-only, maternal-only, or biparental (normal) inheritance. Normal individuals have both a methylated and an unmethylated allele, whereas individuals with PWS have only the maternally methylated allele, therefore the most efficient analysis to diagnose PWS. The most widely used DNA methylation analysis only targets the $5^{\prime} \mathrm{CpG}$ island 
of the SNRPN locus and will correctly diagnose PWS in more than $99 \%$ cases but can not distinguish between a deletion, UPD or ID [3]. A more recent generation of DNA methylation assay, "methylation-specific multiplex-ligation probe amplification" (MS-MLPA) is more informative. MS-MLPA will determine the methylation status by using 5 to 6 methylation probes in the SNRPN locus and other imprinted genes close by to confirm the diagnosis of PWS as well as about 30 probes within the 15q11-q13 region that are used with reference (control) probes outside of the region and on other chromosomes to determine the copy number status [21, 22]. This assay will identify the typical deletion, which is seen in the majority of individuals with PWS as well as the methylation status. If the deletion is not seen with MS-MLPA testing and the PWS methylation pattern is present, then high-resolution microarrays including SNP probes should be used to help identify an imprinting defect or maternal disomy 15 status. In some families more testing will be needed including genotyping of chromosome 15 DNA markers using parental DNA.

\section{Sleep disruption and sleep-disordered breathing}

Sleep disruption and sleep-disordered breathing have been linked to significant deficits in neurocognitive function, including poor focus, excessive daytime sleepiness, and irritability in both the general population [55] and in individuals with PWS [56]. Initially prompted by the daytime feature of hypersomnolence, many individuals with PWS were identified with polysomnographic features of sleepdisordered breathing, including obstructive, central, and mixed sleep apnea syndromes. Factors including developmental brain abnormalities, craniofacial dysmorphia, hypotonia, obesity, and chest wall deformities have been cited as factors that can contribute to both the presence and severity of sleep-disordered breathing in PWS [57]. Following their metanalysis of the literature on sleep-disordered breathing in PWS, Sedky et al. [57] concluded that while obstructive sleep apneas (OSA) were closely related to obesity in non-PWS children, it was unclear whether body mass index (BMI) played a significant role in increasing OSA risk in PWS children. Central apneas were more common in infants studied with PWS [58]. Symptomatic narcolepsy, with or without cataplexy has also been reported in up to $35.7 \%$ of children with PWS [57].

Hypocretin containing neurons, located in the hypothalamus are thought to play an important role in maintaining wakefulness as well as influencing eating behavior. Congenital dysfunction/developmental failure of the hypocretin system has also been proposed as a potential etiology in this population [59-61]. In genome wide expression studies, Bittel et al. [62] reported elevated expression patterns of the hypocretin (HCRT) gene in males with PWS, although an early study by Fronczek et al. [63] did not show a significant difference in the total number of hypocretin-containing neurons among PWS patients and age-matched controls, either in adults or infants.

Excessive daytime sleepiness (EDS) is a very common feature in PWS, occurring in 70-100\% of adults with PWS. Most recently, Mass et al. [64] utilized actigraphic scatter-plots to explore the temporal distribution of EDS with severe disruptive behavior and to identify situations where sleepiness was most likely to occur. Lack of structured activities, particularly in the afternoons and evenings were associated with higher rates of EDS.

$\mathrm{GH}$ is now commonly used in the management of PWS. The effect of $\mathrm{GH}$ during wakefulness has demonstrated improvements in respiratory mechanics and ventilatory responsiveness [65]. More recently, Katz-Solomon et al. [66] performed studies to assess cardiorespiratory control during sleep following the initiation of GH. They demonstrated improved oxygenation and cardiovascular function at 6 months after the initiation of $\mathrm{GH}$ in 16 individuals between ages 2-32 months. However, their study also showed that the ventilatory response to $4 \% \mathrm{CO}_{2}$ and $100 \%$ $\mathrm{O}_{2}$ was essentially unchanged during quiet sleep suggesting that the previous changes were unrelated to an improvement in chemoreflex-mediated autonomic drive [66].

Longitudinal follow-up studies performed after 2 years of GH therapy reported by Al-Saleh et al. [67] in 15 children between 0.8 and 15.4 years (median 3.7 years) showed a median obstructive apnea/hypopnea index (OAHI) of 0.8 (0.3-6.1) and central apnea index (CAI) of 0.9 (0.2-2.3). $\mathrm{GH}$ was discontinued in two of these children due to the development of severe OSA identified by polysomnography at 6 weeks post-initiation of $\mathrm{GH}$ therapy. However, at 2 years post-treatment no significant changes in sleepdisordered breathing were identified in these children, suggesting a period of increased vulnerability in the first few weeks after the initiation of treatment [67].

Berini et al. [68] evaluated adenotonsillar size in 50 children with PWS before the initiation of GH treatment at 6 weeks, at 6 months, at 12 months, and then yearly up to 4 years. Three children developed severe OSA requiring discontinuation of growth hormone therapy. This group found a direct correlation of OAHI with adenoid size but neither with tonsillar size nor with plasma IGF-1 levels [68]. Thus, it is appropriate to screen all individuals with PWS for sleep-disordered breathing. While screening questionnaires and physical examinations may be helpful, neither has shown good specificity or sensitivity [69]. Opinions vary as to the timing and frequency of sleep evaluations but most agree that it is appropriate to study children before the initiation of $\mathrm{GH}$ and then periodically, especially with significant changes in weight, prior to and 
following adeno-tonsillectomy and before spinal or craniofacial surgery.

Whitman and Myers [70] also recommended a repeat polysomnogram at 3-6 months after the initiation of GH in patients with PWS previously diagnosed and treated for OSA as well as regular screening with the Chervin sleep questionnaire (questions 1-6), examination of the oropharynx for tonsillar hypertrophy and monitoring of IGF-1 levels during the entirety of GH therapy. Multiple sleep latency testing (MSLT) is also useful in assessing pathologic sleepiness and is done following an overnight polysomnogram.

In children, adeno-tonsillectomy is the preferred treatment for obstructive sleep apnea. High-risk children including those with PWS and especially those with severe apnea may have residual apneic events and require post-operative evaluation to assess if additional therapies, such as Continuous Positive Airway Pressure (CPAP) are needed [71, 72]. Velopharyngeal dysfunction with hypernasality requiring additional surgical intervention has also been reported following adeno-tonsillectomy in children with PWS [73]. In adults with PWS, CPAP is recommended as the initial therapy due to OSA [74].

\section{Growth hormone (GH) deficiency}

Short stature is a main characteristic of individuals with PWS. Children with PWS fail to show the growth acceleration seen in puberty and the mean final height without treatment is $148 \mathrm{~cm}$ in girls and 155 in boys [75, 76]. Growth charts for non-GH-treated infants and children with PWS have been developed [77, 78]. Non-PWS obese children have decreased GH secretion while maintaining normal serum insulin-like growth factor-1 (IGF-1) levels and normal height. Children with PWS have short stature with low serum GH and IGF-1 levels, therefore true GHD [76, 79-81] is considered.

Children with PWS treated with GH through childhood are able to achieve normal adult height [75, 82]. Beneficial effects on body weight, body composition, and exercise capacity found in these studies prompted studies looking at the effects of GH unrelated to height. In one study, 60 prepubertal children ages 3.13-7.16 years had normal height and positive long-term effects on maintaining body composition after 8 years of GH treatment without any adverse effect on glucose homeostasis, serum lipids, blood pressure, and bone maturation [83].

Anabolic effects of $\mathrm{GH}$ including increase in lean body mass, motor strength, and decrease in fat mass were reported in 21 children when started at $13 \pm 6$ months of age for a period of 6 years and compared with 27 untreated children of similar age [80]. A recent study reported low
BMI in $61.5 \%$ (33.8\% osteoporosis and $27.7 \%$ osteopenia) of 101 patients with a mean age of 5.4 years (range 3-17 years.) and significant improvement after GH treatment for a mean period of 54 months (range 6-144 months) [84].

The beneficial effect of GH therapy in childhood into adulthood is unclear after GH is discontinued. A report of GH treatment discontinuation after 12 and 24 months in 14 individuals with PWS revealed an increase in BMI-SDS $(P=0.008$ and $P=0.003)$ and visceral fat $(P=0.062$ and $P=0.125$ ), respectively [85]. In one study, however, improved mean BMI (32.4 vs. 41.2), body composition, lower mean hemoglobin A1c, lower mean insulin resistance, and less hypertension were reported in 20 adults (mean age 25.4 years) with PWS at 7.0 \pm 4.4 years after discontinuing treatment initiated at age $11.8 \pm 2.7$ years when compared with 40 untreated PWS adult group [86]. Butler et al. [87] studied 11 adults with PWS (average age $=32$ years) over a 2-year period with GH treatment during the first year only. Total lean muscle mass and moderate-vigorous physical activity and plasma IGF-1 and high density lipid (HDL) levels were significantly increased while on $\mathrm{GH}$, while percent body fat decreased during the 12 months of GH treatment. IGF-1 and HDL levels returned to near baseline and body fat increased after $\mathrm{GH}$ treatment during the second year. In addition to improved body composition, increase in muscle strength and exercise tolerance has been reported after 12 and 24 months of GH treatment in 15 obese adults with PWS [88]. Cardiovascular features in obese PWS adults including smaller left ventricular size and lower systolic function are similar to those reported in adult GHD [89]. In one study, left ventricular mass increased significantly after 1 and 2 years of GH treatment $(0.40 \pm 0.11$ to $0.97 \pm 0.17 \mathrm{mg} /$ days $)$ in 9 adult PWS individuals without evident abnormalities of systolic and diastolic function [90]. These data indicate that beneficial effects of GH are still present even after the epiphyses are fused and long-term GH treatment, in addition to strict diet and exercise program may be necessary to maintain good body composition.

Beneficial cognitive effects have been reported in children [91-93] and adults [94] with PWS during GH treatment. Recent study in 19 children with PWS at median age 6.3 years, showed no changes in cognition and behavior over one or two years of GH treatment [95]. These children however, had marked deterioration in behavior at 6 months after abrupt GH discontinuation. These studies demonstrated that GH maintenance therapy may prevent or slow down the progression of behavioral problems in PWS individuals.

Recombinant human growth hormone (hGH) was FDA approved in the United States in 2000 for the indication of short stature and growth failure due to PWS. In Europe, 
growth retardation is not required whereas improvement of body composition is included in the approved indication of GH therapy in PWS [96]. Recommended starting dose in children is $0.18-0.3 \mathrm{mg} / \mathrm{kg} /$ week given as daily subcutaneous injections with careful monitoring of clinical status, bone age, and serum IGF-1 levels at regular intervals. Potential concerns related to excessively high IGF-1 levels include lymphoid hyperplasia leading to OSA and a theoretical increase in malignancy risk. In one study, IGF-1 and IGF-binding protein-3 (IGFBP3) levels were evaluated over a 2-year period in a group of 33 children with PWS treated with GH. These subjects were compared to 591 subjects treated for GH deficiency. The PWS group had significantly higher IGF-1 levels despite lower doses of GH. However, there was no significant difference in IGF-1 to IGFBP3 molar ratios between the groups, suggesting that bioavailable IGF-1, and therefore risk for adverse effects, may be similar in both groups [97]. In view of existing information, GH dose based on ideal rather than actual body weight and monitoring serum IGF-1 levels between 0 and +2 SDS and/or IGF-1/IGFBP3 molar ratio without exceeding GH pretreatment should be considered to prevent abnormal serum IGF-1 elevation, insulin resistance, and occasional acromegaloid features seen in children with PWS at standard recommended GH dose.

The prevalence of scoliosis in PWS is high (30-80\%) [98, 99]. Scoliosis is a major concern for patients with PWS treated with GH. Prevalence, onset, and progression of scoliosis are not affected by the genotype or by growth hormone treatment [75, 100-103]. Therefore, scoliosis is no longer a contraindication for GH treatment in children with PWS. However, due to the high prevalence of scoliosis and the potentially associated morbidities in patients with PWS, regular physical examinations and periodic radiographic evaluations of the spine are recommended.

Significant attention has been given to the association of GH therapy and sudden death in PWS. In a review of 64 cases of death in children from a few days to 19 years of age, 28 subjects (44\%) received GH treatment [104]. Respiratory disorders were the most common cause of death among treated and untreated patients. In this review, most of the deaths in GH-treated children $(75 \%)$ occurred during the first 9 months after the initiation of GH treatment. High mortality rate and increased risk of sudden infant death have been reported in children with PWS independent of GH therapy and without evidence of an association between death and GH treatment $[105,106]$. In view of these data, the initiation of $\mathrm{GH}$ is recommended at the lower dose, $0.18 \mathrm{mg} / \mathrm{kg} /$ week in infants with PWS.

Benefits have been reported with increased lean body mass and decreased body fat mass after 6-12 months GH treatment in adults [107-110]; however, GH is not FDA approved for adult PWS individuals unless confirmed by standard adult GH stimulation testing. The prevalence of GH deficiency in adults with PWS ranges from 15 to $95 \%$, depending on the agents used for stimulation testing and the threshold GH level used to define deficiency [107, 108]. A normal IGF-1 level does not exclude the diagnosis of GHD and provocative testing is mandatory to make the diagnosis of adult GH deficiency (AGHD). The Endocrine Society (ES) recommends that the insulin tolerance test (ITT) and the GHRH- arginine test are sufficiently sensitive and specific to establish the diagnosis of AGHD. Glucagon stimulation test can also be used when GHRH is not available and performance of an ITT is either contraindicated or not practical in a given patient [111]. It is recommended that $\mathrm{GH}$ dosing regimens be individualized rather than weight-based and to start with low doses $(0.1-0.2 \mathrm{mg})$ then titrated according to clinical response, side effects, and IGF-1 levels.

\section{Hypogonadism}

The term "congenital hypogonadism" refers to complete or partial pubertal failure due to insufficient secretion of the pituitary gonadotropins LH and FSH and gonadal sex steroids. Hypogonadism represents a common clinical feature in PWS. Clitoral and labia minora hypoplasia in females and micropenis with hypoplastic scrotal sac in males are evident at birth. Unilateral or bilateral cryptorchidism is present in 80-90\% of males [5]. Similar to many other manifestations of PWS, hypogonadism has been classically thought to be hypothalamic in etiology. However, recent evidence has emerged supporting primary gonadal failure as a significant contributor to male hypogonadism [112114]. Other studies have also shown a combined picture of hypogonadotropic hypogonadism with relatively low LH levels, and primary hypogonadism with low inhibin B and relatively high FSH levels $[114,115]$.

The transient increase in gonadotropins and gonadal hormonal levels occurs during the first months of life, and "minipuberty" is normal in infants with PWS $[116,117]$. Gonadotropins and testosterone play important roles in testicular descend. If hypogonadotropic hypogonadism is present in boys, decreased LH, FSH, testosterone, and inhibin B levels are found in addition to a micropenis (stretched penis $<2.5 \mathrm{~cm}$ ) and cryptorchidism. These findings suggest that additional factors may be responsible for the high incidence of cryptorchidism in infants with PWS.

Gonadal function has also been evaluated longitudinally in 61 girls with PWS. LH levels were found to be relatively low for the low estradiol levels observed, and FSH levels were normal. Although the girls had a normal onset of puberty, the progression was delayed in comparison to the normal population [118]. The pattern of gonadal 
dysfunction in PWS females (primary and combination of a primary gonadal defect and hypothalamic dysfunction) seems to be similar to those observed in boys, male adolescents, and adults with PWS [119, 120]. Four females with PWS diagnosed as children (3 with deletions and one with UPD) with onset of menarche in their $20 \mathrm{~s}$ became pregnant and delivered children by caesarian section. Two of these mothers had normal children and the two PWS mothers with 15q11-q13 deletions delivered a male and a female with Angelman syndrome also with the deletion [121, 122].

Due to high prevalence of premature adrenarche in PWS [123-125], commonly associated with pubic or axillar hair, careful assessment, preferably using a Prader orchidometer, is necessary to demonstrate further testicular enlargement as a first sign of puberty in males (testicular volume greater than $4 \mathrm{ml}$ indicates onset of puberty) and breast development Tanner stage II as the first sign of puberty in females with PWS. During adolescence, the laboratory diagnosis of hypogonadotropic hypogonadism is relatively simple with the identification of very low circulating total testosterone and low to low-normal gonadotropin and inhibin B levels. This hormone profile rules out a primary testicular disorder in which testosterone and inhibin B levels are low, whereas FSH and LH are elevated. Serum FSH, LH, estrogen, and inhibin B profiles are recommended in females with PWS before considering sex hormone replacement therapy (SHRT).

The beneficial effect of sex steroids on the muscle mass and bone health in an individual is well known. Previous studies have suggested that sex steroid deficiency contributes to low bone density in adults with PWS [126, 127]. However, no consensus statement exists as to the most appropriate regimen of sex hormone treatment in PWS. The choice of a particular hormone replacement therapy protocol will depend on the age at diagnosis and local practices. In a recent study, the administration of human chorionic gonadotropin (hCG) 250-500 IU intramuscular biweekly injections for 6 weeks in 16 infants (median age 1.6 years) with PWS with undescended testes resulted in an anatomical lower testis position in most and $23 \%$ had complete scrotal descent. Orchidopexy was required in $76 \%$ of cases in order to ensure a stable position in the scrotum [128]. Furthermore, the American Academy of Pediatrics, Committee on Genetics recommends a therapeutic trial of hCG before considering surgery for undescended testes [129]. The benefits of this modality of treatment include avoidance of general anesthesia, increased scrotal sac size and phallus length to facilitate circumcision/micturition, and thereby improving surgical outcomes for undescended testes.

Testosterone replacement treatment can also lead to improvement in quality of life in males with hypogonadism [130]. In general practice, injectable testosterone is preferred for reasons of convenience and cost. Testosterone enanthate (TE), one of the preparations available on the international market, can be injected once every 2 or 3 weeks in adult males with hypogonadism [131]. It has been thought that TE may increase aggressiveness, but this has not been clearly demonstrated. However, it seems reasonable to start as low as $25 \%$ of the recommended normal adult TE dose (200-250 mg) with gradual increase as tolerated to keep low-normal serum testosterone levels in males while under an endocrinologist's guidance. Virilization of male patients can also be achieved by percutaneous testosterone administration in gel or patch form. However, these alternatives are expensive and require daily administration, raising problems of adherence and the risk for skin irritation and skin picking behavior in PWS.

Guidelines for hormonal replacement therapy in females with PWS are tailored individually depending on sexual development, hormonal profiles, bone density, and emotional and social needs. Oral estrogen alone or in combinations with progestin is well tolerated. Girls with PWS have normal or near normal secondary sexual characteristics including breast development and menses may occur indicating a lesser degree of hypothalamic-gonadal dysfunction in females and therefore counseling about the risk of pregnancy and discussion of birth control during reproductive age would be advisable.

\section{Hypothyroidism}

Similar to other endocrinopathies in PWS, the etiology of hypothyroidism is thought to be central in origin. Hypothyroidism has been reported in approximately 20-30\% of children with PWS [132]. Yet, in one study of 47 individuals with PWS age 10-44 years, the prevalence of hypothyroidism was $2.1 \%$ and not different than the normal population of $2 \%$ [133]. Based on low total (T4) and free thyroxine (FT4) in the presence of normal thyroid-stimulating hormone (TSH), one study reported a prevalence of $72.2 \%$ of central hypothyroidism in children with PWS less than 2 years of age [134]. A recent study revealed normal newborn screening in 23 neonates with PWS for congenital hypothyroidism. In the same study, TSH response to thyroid-releasing hormone (TRH), T4 and FT4 in 21 children from birth to adolescence showed normal patterns except in one elder child with central hypothyroidism [135]. Based on these studies, the prevalence of hypothyroidism is variable and cannot be clearly established. Thus, levothyroxine treatment should not be routinely prescribed in children with PWS unless confirmed by thyroid function testing. It is recommended that baseline thyroid function testing (FT4 and TSH) be done during the first 3 months of life unless they have had a normal newborn screening and 
annually thereafter, especially if the patient is receiving GH therapy.

\section{Adrenal insufficiency}

Based on generalized hypothalamic dysfunction, children and adults with PWS are at risk for central adrenal insufficiency (CAI). The first published cross-sectional analysis in 2008 of adrenal insufficiency in children with PWS, reported CAI in $60 \%$ of cases after receiving an overnight single-dose of metyrapone [136]. However, five subsequent studies using different methodologies, including low- and high-dose Synacthen and insulin tolerance testing did not confirm the reported high frequency of CAI [137-141].

Isolated ACTH insufficiency is rare but it may be a component of a multiple hormone deficiency (MPHD). Development of additional pituitary hormone deficiencies in children with acquired MPHD or initially diagnosed with growth hormone deficiency (GHD) is characterized by a sequential order of hormonal loss, usually GH, TSH, LH/FSH, and ACTH [142]. In adults, LH/FSH disturbances have been reported after GH problems, then followed by TSH and with ACTH being the last pituitary hormone deficiency [143]. Although additional inherent and exogenous factors may regulate adrenal androgen production, normal ACTH secretion action is needed for adrenarche [144-146], which is increased in children with PWS. The true prevalence of CAI in PWS therefore remains unclear with no consensus present among endocrinologists as to whether evaluation should be done for CAI and/or glucocorticoid treatment preoperative or during significant stress.

Metyrapone $(30 \mathrm{mg} / \mathrm{kg}$ orally at midnight) inhibits 11-hydroxylase, the final step in cortisol synthesis, thereby decreasing cortisol secretion and subsequently increasing ACTH secretion. Using metyrapone is a cumbersome test that is rarely performed because of the difficulty in obtaining metyrapone and the risk of precipitating an adrenal crisis. Hence, parents of children with PWS should be counseled about symptoms consistent with adrenal insufficiency and physicians alerted to the risk and treated accordingly should symptoms occur. In summary, PWS is a classic example of a genetic disorder requiring a complex multidiscipline approach to treat ongoing growth, medical, and endocrine disturbances common to all individuals throughout the natural history of this condition.

Funding This research did not receive any specific grant from any funding agency in the public, commercial or not-for profit sector.

Conflict of interest The authors declare that they have no conflict of interest.
Ethical approval This manuscript is a review of the literature on the subject of Prader-Willi syndrome and does not contain original research either on animals or human subjects.

Informed consent For this type of study formal consent is not required.

Open Access This article is distributed under the terms of the Creative Commons Attribution 4.0 International License (http://creativecommons.org/licenses/by/4.0/), which permits unrestricted use, distribution, and reproduction in any medium, provided you give appropriate credit to the original author(s) and the source, provide a link to the Creative Commons license, and indicate if changes were made.

\section{References}

1. Prader A, Labhart A, Willi H (1956) Ein Syndrom von Adipositas, Kleinwuchs, Kryptorchismus und Oligophrenie nach myatonieartigem Zustand im neugeborenenalter. Schweiz Med Wochenschr 86:1260-1261

2. Bittel DC, Butler MG (2005) Prader-Willi syndrome: clinical genetics, cytogenetics and molecular biology. Expert Rev Mol Med 7(14):1-20

3. Butler MG, Lee PDK, Whitman BY (2006) Management of Prader-Willi Syndrome. Springer, New York

4. Butler MG (2011) Prader-Willi syndrome: obesity due to genomic imprinting. Curr Genomics 12:204-215

5. Cassidy SB, Schwartz S, Miller JL, Driscoll DJ (2012) PraderWilli syndrome. Genet Med 14(1):10-26

6. Aycan Z, Bas VN (2014) Prader-Willi syndrome and growth hormone deficiency. J Clin Res Pediatr Endocrinol 6(2):62-67

7. Buiting K (2010) Prader-Willi syndrome and Angelman syndrome. Am J Med Genet C Semin Med Genet 154C:365-376

8. Williams CA, Driscoll DJ, Dagli AI (2010) Clinical and genetic aspects of Angelman syndrome. Genet Med 12(7):385-395

9. Nicholls RD, Knoll JH, Butler MG, Karam S, Lalande M (1989) Genetic imprinting suggested by maternal heterodisomy in nondeletion Prader-Willi syndrome. Nature 342(6247):281-285

10. Nicholls RD, Knepper JL (2001) Genome organization, function, and imprinting in Prader-Willi and Angelman syndromes. Ann Rev Genomics Hum Genet 2:153-175

11. Buiting K, Gross S, Lich C, Gillessen-Kaesbach G, El-Maarri O, Horsthemke B (2003) Epimutations in Prader-Willi and Angelman syndromes: a molecular study of 136 patients with an imprinting defect. Am J Hum Genet 72(3):571-577

12. Butler MG, Thompson T (2000) Prader-Willi syndrome: clinical and genetic finding. Endocrinology 10:3S-16S

13. Butler MG (1990) Prader-Willi syndrome: current understanding of cause and diagnosis. Am J Med Genet 35(3):319-332

14. Sun Y, Nicholls RD, Butler MG, Saitoh S, Hainline BE, Palmer CG (1996) Breakage in the SNRPN locus in a balanced 46, XY, t $(15 ; 19)$ Prader-Willi syndrome patient. Hum Mol Genet 5(4):517-524

15. Butler MG, Christian SL, Kubota T, Ledbetter DH (1996) A 5-year-old white girl with Prader-Willi syndrome and a submicroscopic deletion of chromosome 15q11q13. Am J Med Genet 65(2):137-141

16. Kim SJ, Miller JL, Kuipers PJ, German JR, Beaudet AL, Sahoo T, Driscoll DJ (2012) Unique and atypical deletions in PraderWilli syndrome reveal distinct phenotypes. Eur J Hum Genet 20(3):283-290

17. Rocha CF, Paiva CL (2014) Prader-Willi-like phenotypes: a systematic review of their chromosomal abnormalities. Genet Mol Res 1:2290-2298 
18. Butler MG (2009) Genomic imprinting disorders in humans: a mini-review. J Assist Reprod Genet 26(9-10):477-486

19. Holm VA, Cassidy SB, Butler MG, Hanchett JM, Greenswag LR, Whitman BY, Greenberg F (1993) Prader-Willi syndrome: consensus diagnostic criteria. Pediatrics 91(2):398-402

20. Gunay-Aygun M, Schwartz S, Heeger S, O'Riordan MA, Cassidy SB (2001) The changing purpose of Prader-Willi syndrome clinical diagnostic criteria and proposed revised criteria. Pediatrics 108(5):E92

21. Bittel DC, Kibiryeva N, Butler MG (2007) Methylation-specific multiplex ligation-dependent probe amplification analysis of subjects with chromosome 15 abnormalities. Genet Test 11(4):467-475

22. Henkhaus RS, Kim SJ, Kimonis VE, Gold JA, Dykens EM, Driscoll DJ, Butler MG (2012) Methylation-specific multiplex ligation-dependent probe amplification and identification of deletion genetic subtypes in Prader-Willi syndrome. Genet Test Mol Biomarkers 16(3):178-186

23. Miller JL, Lynn CH, Driscoll DC, Goldstone AP, Gold JA, Kimonis V, Dykens E, Butler MG, Shuster JJ, Driscoll DJ (2011) Nutritional phases in Prader-Willi syndrome. Am J Med Genet A 155(5):1040-1049

24. Cummings DE, Clement K, Purnell JQ, Vaisse C, Foster KE, Frayo RS, Schwartz MW, Basdevant A, Weigle DS (2002) Elevated plasma ghrelin levels in Prader-Willi syndrome. Nat Med 8(7):643-644

25. Del Parigi A, Tschöp M, Heiman ML, Salbe AD, Vozarova B, Sell SM, Bunt JC, Tataranni PA (2002) High circulating ghrelin: a potential cause for hyperphagia and obesity in PraderWilli syndrome. J Clin Endocrinol Metab 87:5461-5464

26. Tan TM-M, Vanderpump M, Khoo B, Patterson M, Ghatei MA, Goldstone AP (2004) Somatostatin infusion lowers plasma ghrelin without reducing appetite in adults with Prader-Willi syndrome. J Clin Endocrinol Metab 89(8):4162-4165

27. De Waele K, Ishkanian SL, Bogarin R, Miranda CA, Ghatei MA, Bloom SR, Pacaud D, Chanoine JP (2008) Long-acting octreotide treatment causes a sustained decrease in ghrelin concentrations but does not affect weight, behaviour and appetite in subjects with Prader-Willi syndrome. Eur J Endocrinol 159(4):381-388

28. Kweh FA, Miller JL, Sulsona CR, Wasserfall C, Atkinson M, Shuster JJ, Goldstone AP, Driscoll DJ (2015) Hyperghrelinemia in Prader-Willi syndrome begins in early infancy long before the onset of hyperphagia. Am J Med Genet A 167(1):69-79

29. Butler JV, Whittington JE, Holland AJ, Boer H, Clarke D, Webb $T$ (2002) Prevalence of, and risk factors for, physical ill-health in people with Prader-Willi syndrome: a population-based study. Dev Med and Child Neurol 44(4):248-255

30. Haqq AM, Muehlbauer MJ, Newgard CB, Grambow S, Freemark M (2011) The metabolic phenotype of PraderWilli syndrome (PWS) in childhood: heightened insulin sensitivity relative to body mass index. J Clin Endocrinol Metab 96:E225-E232

31. Diene G, Mimoun E, Feigerlova E et al (2010) French Reference Centre for PWS. Endocrine disorders in children with Prader-Willi syndrome-data from 142 children of the French database. Horm Res Paediatr 74:121-128

32. Waterland RA, Jirtle RL (2004) Early nutrition, epigenetic changes at transposons and imprinted genes, and enhanced susceptibility to adult chronic diseases. Nutrition 20(1):63-68

33. Bittel DC, Kibiryeva N, Talebizadeh Z, Butler MG (2003) Microarray analysis of gene/transcript expression in Prader-Willi syndrome: deletion versus UPD. J Med Genet 40(8):568-574

34. Bittel DC, Kibiryeva N, Talebizadeh Z, Driscoll DJ, Butler MG (2005) Microarray analysis of gene/transcript expression in Angelman syndrome: deletion versus UPD. Genomics 85(1):85-91

35. Sahoo T, del Gaudio D, German JR, Shinawi M, Peters SU, Person RE, Garnica A, Cheung SW, Beaudet AL (2008) PraderWilli phenotype caused by paternal deficiency for the HBII-85 C/D box small nucleolar RNA cluster. Nat Genet 40(6):719-721

36. de Smith AJ, Purmann C, Walters RG, Ellis RJ, Holder SE, Van Haelst MM, Brady AF, Fairbrother UL, Dattani M, Keogh JM, Henning E, Yeo GS, O'Rahilly S, Froguel P, Farooqi IS, Blakemore AI (2009) A deletion of the HBII-85 class of small nucleolar RNAs (snoRNAs) is associated with hyperphagia, obesity and hypogonadism. Hum Mol Genet 18(17):3257-3265

37. Bieth E, Eddiry S, Gaston V, Lorenzini F, Buffet A, Conte Auriol F, Molinas C, Cailley D, Rooryck C, Arveiler B, Cavaille J, Salles JP, Tauber M (2015) Highly restricted deletion of the SNORD116 region is implicated in Prader-Willi syndrome. Eur J Hum Genet 23(2):252-255

38. Kishore S, Stamm S (2006) The snoRNA HBII-52 regulates alternative splicing of the serotonin receptor 2C. Science 311(5758):230-232

39. Schaaf CP, Gonzalez-Garay ML, Xia F, Potocki L, Gripp KW, Zhang B, Peters BA, McElwain MA, Drmanac R, Beaudet AL, Caskey CT, Yang Y (2013) Truncating mutations of MAGEL2 cause Prader-Willi phenotypes and autism. Nat Genet 45(11):1405-1408

40. Macedo DB, Abreu AP, Reis AC, Montenegro LR, Dauber A, Beneduzzi D, Cukier P, Silveira LF, Teles MG, Carroll RS, Junior GG, Filho GG, Gucev Z, Arnhold IJ, de Castro M, Moreira AC, Martinelli CE Jr, Hirschhorn JN, Mendonca BB, Brito VN, Antonini SR, Kaiser UB, Latronico AC (2014) Central precocious puberty that appears to be sporadic caused by paternally inherited mutations in the imprinted gene makorin ring finger 3 . J Clin Endocrinol Metab 99(6):E1097-E1103

41. Buiting K, Nazlican H, Galetzka D, Wawrzik M, Gross S, Horsthemke B (2007) C15orf2 and a novel noncoding transcript from the Prader-Willi/Angelman syndrome region show monoallelic expression in fetal brain. Genomics 89(5):588-595

42. Chai JH, Locke DP, Greally JM, Knoll JH, Ohta T, Dunai J, Yavor A, Eichler EE, Nicholls RD (2003) Identification of four highly conserved genes between breakpoint hotspots BP1 and BP2 of the Prader-Willi/Angelman syndromes deletion region that have undergone evolutionary transposition mediated by flanking duplicons. Am J Hum Genet 73(4):898-925

43. Butler MG (1989) Hypopigmentation: a common feature of Prader-Labhart-Willi syndrome. Am J Hum Genet 45(1):140-146

44. Butler MG, Fischer W, Kibiryeva N, Bittel DC (2008) Array comparative genomic hybridization $(\mathrm{aCGH})$ analysis in PraderWilli syndrome. Am J Med Genet Part A 146A(7):854-860

45. Bittel DC, Kibiryeva N, Butler MG (2006) Expression of 4 genes between chromosome 15 breakpoints 1 and 2 and behavioral outcomes in Prader-Willi syndrome. Pediatrics 118(4):e1276-e1283

46. Svenstrup K, Moller RS, Christensen J, Budtz-Jorgensen E, Gilling M, Nielsen JE (2011) NIPA1 mutation in complex hereditary spastic paraplegia with epilepsy. Eur J Neurol 18(9):1197-1199

47. Burnside RD, Pasion R, Mikhail FM, Carroll AJ, Robin NH, Youngs EL, Gadi IK, Keitges E, Jaswaney VL, Papenhausen PR, Potluri VR, Risheg H, Rush B, Smith JL, Schwartz S, Tepperberg JH, Butler MG (2011) Microdeletion/microduplication of proximal $15 \mathrm{q} 11.2$ between BP1 and BP2: a susceptibility region for neurological dysfunction including developmental and language delay. Hum Genet 130(4):517-528

48. Jerkovich AM, Butler MG (2014) Further phenotypic expansion of 15q11.2 BP1-BP2 microdeletion (Burnside-Butler) syndrome. J Ped Genet 3(1):41-44 
49. Cox DM, Butler MG (2015) The 15q11.2 BP1-BP2 microdeletion syndrome: a review. Int J Mol Sci 16(2):4068-4082

50. Butler MG, Bittel DC, Kibiryeva N, Talebizadeh Z, Thompson $\mathrm{T}$ (2004) Behavioral differences among subjects with PraderWilli syndrome and type I or type II deletion and maternal disomy. Pediatrics 113:565-573

51. Zarcone J, Napolitano D, Peterson C, Breidbord J, Ferraioli S, Caruso-Anderson M, Holsen L, Butler MG, Thompson T (2007) The relationship between compulsive behaviour and academic achievement across the three genetic subtypes of PraderWilli syndrome. J Intellect Disabil Res 51:478-487

52. Cassidy SB, Lai LW, Erickson RP, Magnuson L, Thomas E, Gendron R, Herrmann J (1992) Trisomy 15 with loss of the paternal 15 as a cause of Prader-Willi syndrome due to maternal disomy. Am J Hum Genet 51:701-708

53. Butler MG, Sturich J, Myers SE, Gold JA, Kimonis V, Driscoll DJ (2009) Is gestation in Prader-Willi syndrome affected by the genetic subtype? J Assist Reproduct Genet 26(8):461-466

54. Newkirk HL, Bittel DC, Butler MG (2008) Analysis of the Prader-Willi syndrome chromosome region using quantitative microsphere hybridization (QMH) array. Am J Med Genet Part A 146A(18):2346-2354

55. Beebe D (2006) Neurobehavioral morbidity associated with disordered breathing during sleep in children: a comprehensive review. Sleep 29(9):1115-1134

56. Maas AP, Sinnema M, Didden R, Maaskant MA, Smits MG, Schrander-Stumpel CT, Curfs LM (2010) Sleep disturbances and behavioral problems in adults with PWS. J Intellect Disabil Res 54:906-917

57. Sedky K, Bennett DS, Pumariega A (2014) Prader-Willi syndrome and obstructive sleep apnea: co-occurrence in the pediatric population. J Clin Sleep Med 10(4):403-409

58. Bruni O, Verrillo E, Novellia L, Ferric R (2010) Prader-Willi Syndrome: sorting out the relationships between obesity, hypersomnia and sleep apnea. Curr Opin Pulm Med 16:568-573

59. Weselake SV, Foulds JL, Couch R et al (2014) Prader-Willi syndrome, excessive daytime sleepiness and narcoleptic symptoms: a case report. J Med Case Rep 8:127

60. Nishino S, Kanbayashi T (2005) Symptomatic narcolepsy, cataplexy and hypersomnia and their implications in the hypothalamic hypocretin/orexin system. Sleep Med Rev 9(4):269-310

61. Arii J, Kanbayashi T, Tanabe Y et al (2004) CSF hypocretin 1 levels in childhood narcolepsy and neurologic disorders. Neurology 63(12):2440-2442

62. Bittel DC, Kibiryeva N, Sell SM, Strong TV, Butler MG (2007) Whole genome microarray analysis of gene expression in Prader-Willi syndrome. Am J Med Genet 143A(5):430-442

63. Fronczek R, Lammers J, Balesar R et al (2005) The number of hypothalamic hypocretin neurons is not affected in Prader-Willi syndrome. J Clin Endocrinol Metab 90:5466-5470

64. Maas AP, Didden R, Bouts L, Smits MG, Curfs LM (2009) Scatter plot analysis of excessive daytime sleepiness and severe disruptive behavior in adults with PWS: a pilot study. Res Dev Disabil 30:529-537

65. Lindgren AC, Hellstrom LG, Ritzen EM, Milerad J (1999) Growth hormone treatment increases $\mathrm{CO} 2$ response, ventilation and central inspiratory drive in children with PWS. Eur J Pediatr 158:936-940

66. Katz-Solomon M, Lindgren AC, Cohen G (2012) The effect of growth hormone on sleep related cardiopulmonary control in PWS. Acta Paediatr 101(6):643-648

67. Al-Saleh S, Al-Naimi A, Hamilton J et al (2013) Longitudinal evaluation of sleep disordered breathing in children with PWS during 2 years of growth hormone therapy. J Pediatr $162: 263-268$
68. Berini J, Spica-Russotto V, Castelnuevo P et al (2013) Growth hormone therapy and respiratory disorders: long term follow-up in PWS children. J Clin Endocrinol Metab 98(9):E1516-E1523

69. Katz ES, Marcus CL (2014) Diagnosis of obstructive sleep Apnea syndrome in infants and children. In: Sheldon SH, Ferber R, Kryger M, Gozal D (eds) Principles and practice of pediatric sleep medicine, 2nd edn. Elsevier, New York, pp 321-322

70. Whitman BY, Myers SE (2013) Prader-Willi syndrome and growth hormone therapy: take a deep breath and weigh the data. J Peds 162(2):224-226

71. Bhattacharjee R, Kheirandish-Gozal LK, Spruyt K et al (2010) Adenotonsillectomy outcomes in treatment of obstructive sleep apnea in children. Am J Respir Crit Care Med 182:676-683

72. Meyer SL, Splaingard M, Repaske DR et al (2012) Outcomes of adenotonsillectomy in patients with Prader-Willi syndrome. Arch Otolaryngol Head Neck Surg 138(11):1047-1051

73. Crockett DJ, Ahmed SR, Sowder DR et al (2014) Velopharyngeal dysfunction in children with Prader-Willi syndrome after adenotonsillectomy. Int $\mathrm{J}$ Ped Otorhinolaryngology 78:1731-1734

74. Qaseem A, Holty JE, Owens DK, Dallas P, Starkey M, Shekelle P, For the Clinical Guidelines Committee of the American College of Physicians (2013) Management of obstructive sleep Apnea in adults: a clinical practice guideline from the American College of Physicians. Ann Intern Med 159(7):471-483

75. Angulo MA, Castro-Magana M, Lamerson M, Arguello R, Accacha S, Khan A (2007) Final adult height in children with Prader-Willi syndrome with and without human growth hormone treatment. Am J Med Genet A 143A(13):1456-1461

76. Cassidy SB, Schwartz S, Miller JL, Driscoll DJ (2012) PraderWilli syndrome. Genet Med 14(1):10-26

77. Butler MG, Sturich J, Lee J, Myers SE, Whitman BY, Gold JA, Kimonis V, Scheimann A, Terrazas N, Driscoll DJ (2011) Growth standards of infants with Prader-Willi syndrome. Pediatrics 127(4):687-695

78. Butler MG, Lee J, Manzardo AM, Gold JA, Miller JL, Kimonis V, Driscoll DJ (2015) Growth charts for non-growth hormone treated Prader-Willi syndrome. Pediatrics 135(1):e126-e135

79. Grugni G, Crinò A, Pagani S, Meazza C, Buzi F, De Toni T, Gargantini L, Pilotta A, Pozzan GB, Radetti G, Ragusa L, Salvatoni A, Sartorio A (2011) Growth hormone secretory pattern in non-obese children and adolescents with Prader-Willi syndrome. J Pediatr Endocrinol Metab 24(7-8):477-481

80. Carrel AL, Myers SE, Whitman BY, Eickhoff J, Allen DB (2010) Long-term growth hormone therapy changes the natural history of body composition and motor function in children with Prader-Willi syndrome. J Clin Endocrinol Metab 95:1131-1136

81. Angulo M, Castro-Magana M, Mazur B, Canas JA, Vitollo PM, Sarrantonio M (1996) Growth hormone secretion and effects of growth hormone therapy on growth velocity and weight gain in children with Prader-Willi syndrome. J Pediatr Endocrinol Metab 9(3):393-400

82. Eiholzer U, l'Allemand D (2000) Growth hormone normalizes height, prediction of final height and hand length in children with Prader-Willi syndrome after 4 years of therapy. Horm Res 53(4): 185-192

83. Bakker NE, Kuppens RJ, Siemensma EP et al (2013) Eight years of growth hormone treatment in children with PraderWilli syndrome: maintaining the positive effects. J Clin Endocrinol Metab 98(10):4013-4022

84. Nakamura Y, Murakami N, Iida T, Asano S, Ozeki S, Nagai $\mathrm{T}$ (2014) Growth hormone treatment for osteoporosis in patients with scoliosis of Prader-Willi syndrome. J Orthop Sci 19:877-882 
85. Oto Y, Tanaka Y, Abe Y, Obata K, Tsuchiya T, Yoshino A, Murakami N, Nagai T (2014) Exacerbation of BMI after cessation of growth hormone therapy in patients with Prader-Willi syndrome. Am J Med Genet A 164A(3):671-675

86. Coupaye M, Lorenzini F, Llore-Linares C et al (2013) Growth hormone therapy for children and adolescents with PraderWilli syndrome is associated with improved body composition and metabolic status in adulthood. J Clin Endocrinol Metab 98:E328-E335

87. Butler MG, Smith BK, Lee J, Gibson C, Schmoll C, Moore WV, Donnelly JE (2013) Effects of growth hormone treatment in adults with Prader-Willi syndrome. Growth Horm IGF Res 23(3):81-87

88. Lafortuna CL, Minocci A, Capodaglio P, Gondoni LA, Sartorio A, Vismara L, Rizzo G, Grugni G (2014) Skeletal muscle characteristics and motor performance after 2-year growth hormone treatment in adults with Prader-Willi syndrome. J Clin Endocrinol Metab 99:1816-1824

89. Marzullo P, Marcassa C, Campini R, Eleuteri E, Minocci A, Priano L, Temporelli P, Sartorio A, Vettor R, Liuzzi A, Grugni G (2005) The Impact of growth hormone/insulin-like growth factor-I axis and nocturnal breathing disorders on cardiovascular features of adult patients with Prader-Willi syndrome. J Clin Endocrinol Metab 90:5639-5646

90. Marzullo P, Marcassa C, Minocci A, Campini R, Eleuteri E, Alessandro Gondoni L, Aimaretti G, Sartorio A, Scacchi M, Grugni G (2015) Long-term echocardiographic and cardioscintigraphic effects of growth hormone treatment in adults with Prader-Willi syndrome. J Clin Endocrinol Metab. doi:10.1210/ jc2015-1063

91. Myers SE, Whitman BY, Carrel AL, Moerchen V, Bekx MT, Allen DB (2007) Two years of growth hormone therapy in young children with Prader-Willi syndrome: physical and neurodevelopmental benefits. Am J Med Genet A 143A(5):443-448

92. Festen DA, Wevers M, Lindgren AC, Böhm B, Otten BJ, Wit JM et al (2008) Mental and motor development before and during growth hormone treatment in infants and toddlers with Prader-Willi syndrome. Clin Endocrinol 68:919-925

93. Siemensma EP, de Lindvanwijngaarder RF, Festen DA et al (2012) Beneficial effects of growth hormone treatment on cognition in children with Prader-Willi syndrome: a randomized controlled trial and longitudinal study. J Clin Endocrinol Metab 97(7):2307-2314

94. Höybye C, Thorén M, Böhm B (2005) Cognitive, emotional, physical and social effects of growth hormone treatment in adults with Prader-Willi syndrome. J Intellect Disabil Res 49:245-252

95. Böhm B, Ritzén EM, Lindgren AC (2014) Growth hormone treatment improves vitality and behavioural issues in children with Prader-Willi Syndrome. Acta Paediatric 104:59-67

96. Deal CL, Tony M, Höybye C et al (2013) Growth hormone research society workshop summary: consensus guidelines for recombinant human growth hormone therapy in Prader-Willi syndrome. J Clin Endocrinol Metab 98:E1072-E1087

97. Feigerlova E, Diene G, Oliver I, Gennero I, Salles JP, Arnaud C, Tauber M (2010) Elevated insulin-like growth factor-I values in children with Prader-Willi syndrome compared with growth hormone $(\mathrm{GH})$ deficiency children over two years of GH treatment. J Clin Endocrinol Metab 95(10):4600-4608

98. Nagai T, Obata K, Ogata T, Murakami N, Katada Y, Yoshino A, Sakazume S, Tomita Y, Sakuta R, Niikawa N (2006) Growth hormone therapy and scoliosis in patients with Prader-Willi syndrome. Am J Med Genet A 140:1623-1627

99. de Lind van Wijngaarden RF, de Klerk LW, Festen DA, Hokken-Koelega AC (2008) Scoliosis in Prader-Willi syndrome: prevalence, effects of age, gender, body mass index, lean body mass and genotype. Arch Dis Child 93:1012-1016
100. Odent T, Accadbled F, Koureas G, Cournot M, Moine A, Diene G, Molinas C, Pinto G, Tauber M, Gomes B, de Gauzy JS, Glorion $C$ (2008) Scoliosis in patients with Prader-Willi-Syndrome. Pediatrics 122(2):e499-e503

101. Diene G, de Gauzy JS, Tauber M (2008) Is scoliosis an issue for giving growth hormone to children with Prader-Willi syndrome? Arch Dis Childhood 93(12):1004-1006

102. de Lind van Wijngaarden RF, de Klerk LW, Festen DA, Duivenvoorden HJ, Otten BJ, Hokken-Koelega AC (2009) Randomized controlled trial to investigate the effects of growth hormone treatment on scoliosis in children with Prader-Willi syndrome. J Clin Endocrinol Metab 94(4):1274-1280

103. Murakami N, Obata K, Abe Y, Oto Y, Kido Y, Itabashi H, Tsuchiya T, Tanaka Y, Yoshino A, Nagai T (2012) Scoliosis in Prader-Willi syndrome: effect of growth hormone therapy and value of paravertebral muscle volume by CT in predicting scoliosis progression. Am J Med Genet A 158A(7):1628-1633

104. Tauber M, Diene G, Molinas C, Hébert M (2008) Review of 64 cases of death in children with Prader-Willi syndrome (PWS). Am J Med Genet Part A 146(7):881-887

105. Einfeld SL, Kavanagh SJ, Smith A, Evans EJ, Tonge BJ, Taffe J, Dykens E (2006) Mortality in Prader-Willi syndrome. Am J Ment Retard 111(3):193-198

106. Van Vliet G, Deal CL, Crock PA, Robitaille Y, Oligny LL (2004) Sudden death in growth hormone-treated children with Prader-Willi syndrome. J Pediatr 144:129-131

107. Mogul HR, Lee PD, Whitman BY, Zipf WB, Frey M, Myers S, Cahan M, Pinyerd B, Southren AL (2008) Growth hormone treatment of adults with Prader-Willi syndrome and growth hormone deficiency improves lean body mass, fractional body fat, and serum triiodothyronine without glucose impairment: results from the United States multicenter trial. J Clin Endocrinol Metab 93(4): 1238-1245

108. Sode-Carlsen R, Farholt S, Rabben KF, Bollerslev J, Schreiner T, Jurik AG, Christiansen JS, Hoybye C (2012) Growth hormone treatment in adults with Prader-Willi syndrome: the Scandinavian study. Endocrine 41(2): 191-199

109. Sode-Carlsen R et al (2010) One year of growth hormone treatment in adults with Prader-Willi syndrome improves body composition: results from a randomized, placebo-controlled study. J Clin Endocrinol Metab 95(11):4943-4950

110. Sanchez-Ortiga R, Klibanski A, Tritos NA (2012) Effects of recombinant human growth hormone therapy in adults with Prader-Willi syndrome: a meta-analysis. Clin Endocrinol 77(1):86-93

111. Molitch M, Clemmons D, Malozowski S, Merriam G, Vance M (2011) Evaluation and treatment of adult growth hormone deficiency: an endocrine society clinical practice guidelines. J Clin Endocrinol Metab 96(6):1587-1609

112. Vogels A, Moerman P, Frijns JP, Bogaert GA (2008) Testicular histology in boys with Prader-Willi syndrome: fertile or infertile? J Urol 180:1800-1804

113. Siemensma EP, de Lind van Wijngaarden RF, Otten BJ, de Jong FH, Hokken-Koelega AC (2012) Testicular failure in boys with Prader-Willi syndrome: longitudinal studies of reproductive hormones. J Clin Endocrinol Metab 97:E452-E459

114. Radicioni AF, Di Giorgio G, Grugni G, Cuttini M, Losacco V, Anzuini A, Spera S, Marzano C, Lenzi A, Cappa M, Crinó A (2012) Multiple forms of hypogonadism of central, peripheral or combined origin in males with Prader-Willi syndrome. Clin Endocrinol (Oxf) 76:72-77

115. Eiholzer U, l'Allemand D, Rousson V, Schlumpf M, Gasser T, Girard J, Gruters A, Simoni M (2006) Hypothalamic and gonadal components of hypogonadism in boys with Prader-Labhart-Willi syndrome. J Clin Endocrinol Metab 91:892-898 
116. Fillion M, Deal CL, Van Vliet G (2006) Normal minipuberty of infancy in boys with Prader-Willi syndrome. J Pediatr 149:874-876

117. Hirsch HJ, Eldar-Geva T, Erlichman M, Pollak Y, Gross-Tsur V (2014) Characterization of minipuberty in infants with PraderWilli syndrome. Horm Res Paediatr 82:230-237

118. Siemensma EP, van Alfen-van der Velden AA, Otten BJ, Laven JS, Hokken-Koelega AC (2012) Ovarian function and reproductive hormone levels in girls with Prader-Willi syndrome: a longitudinal study. J Clin Endocrinol Metab 97:E1766-E1773

119. Eldar-Geva T, Hirsch HJ, Rabinowitz R, Benarroch F, Rubinstein O, Gross-Tsur V (2009) Primary ovarian dysfunction contributes to the hypogonadism in women with Prader-Willi Syndrome. Horm Res 72(3):153-159

120. Eldar-Geva T, Hirsch HJ, Benarroch F, Rubinstein O, GrossTsur V (2010) Hypogonadism in females with Prader-Willi syndrome from infancy to adulthood: variable combinations of a primary gonadal defect and hypothalamic dysfunction. Eur $\mathbf{J}$ Endocrinol 162(2):377-384

121. Akefeldt A, Tornhage CJ, Gillberg C (1999) A woman with Prader-Willi syndrome gives birth to a healthy baby girl. Dev Med Child Neurol 41:789-790

122. Schulze A, Mogensen H, Hamborg-Petersen B, Graem N, Ostergaard JR, Brondum-Nielsen K (2001) Fertility in PraderWilli syndrome: a case report with Angelman syndrome in the offspring. Acta Paediatr 90:455-459

123. Schmidt H, Schwarz PS (2001) Premature adrenarche, increased growth velocity and accelerated bone age in male patients with Prader-Labhart-Willi syndrome. Eur J Pediatr 160:69-70

124. Angulo MA, Castro-Magana M, Lamerson M, Arguello R, Accacha S, Khan A (2007) Final adult height in children with Prader-Willi syndrome with and without human growth hormone treatment. Am J Med Genet A 143A(13):1456-1461

125. Siemensma EP, Lind van Wijngaarden RF, Otten BJ, de Jong FH, Hokken-Koelega AC (2011) Pubarche and serum dehydroepiandrosterone sulphate levels in children with Prader-Willi syndrome. Clin Endocrinol (Oxf) 75:83-89

126. Butler MG, Haber L, Mernaugh R, Carlson MG, Price R, Feurer ID (2001) Decreased bone mineral density in PraderWilli syndrome: comparison with obese subjects. Am J Med Genet 103:216-222

127. Vestergaard P, Kristensen K, Bruun JM, Østergaard JR, Heickendorff L, Mosekilde L, Richelsen B (2004) Reduced bone mineral density and increased bone turnover in prader-willi syndrome compared with controls matched for sex and body mass index - a cross-sectional study. J Pediatr 144(5):614-619

128. Bakker NE, Wolffenbuttel KP, Looijenga LH, Hokken-Koelega AC (2015) Testes in enfants with Prader-Willi syndrome: human chorionic gonadotropin treatment, surgery and histology. J Urol 193:291-298

129. McCandless SE, Committee in Genetics (2011) Clinical reporthealth supervision for children with Prader-Willi syndrome. Pediatrics 127(1):195-204

130. Young J (2012) Approach to the male patient with congenital hypogonadotropic hypogonadism. J Clin Endocrinol Metab 97:707-718

131. Zitzmann M, Nieschlag E (2000) Hormone substitution in male hypogonadism. Mol Cell Endocrinol 161:73-88

132. Tauber M, Barbeau C, Jouret B, Pienkowski C, Malzac P, Moncla A, Rochiccioli P (2000) Auxological and endocrine evolution of 28 children with Prader-Willi syndrome: effect of GH therapy in 14 children. Horm Res 53(6):279-287

133. Butler M, Theodoro M, Skouse JD (2007) Thyroid function studies in Prader-Willi syndrome. Am J Med Genet Part A 143A:488-492

134. Vaiani E, Herzovich V, ChalerE Chertkoff L, Rivarola MA, Torrado M, Belgorosky A (2010) Thyroid axis dysfunction in patients with Prader-Willi syndrome during the first 2 years of life. Clin Endocrinol (Oxf) 73:546-550

135. Sharkia M, Michaud S, Berthier MT, Giguère Y, Stewart L, Deladoëy J, Deal C, Van Vliet G, Chanoine JP (2013) Thyroid function from birth to adolescence in Prader-Willi syndrome. J Pediatr 163(3):800-805

136. Lind van Wijngaarden RF, Otten BJ, Festen DA, Joosten KF, de Jong FH, Sweep FC, Hokken-Koelega AC (2008) High prevalence of central adrenal insufficiency in patients with PraderWilli syndrome. J Clin Endocrinol Metab 93:1649-1654

137. Grugni G, Beccaria L, Corrias A, Crino A, Cappa M, De Medici C, Candia SD, Gargantini L, Ragusa L, Salvatoni A et al (2013) Central adrenal insufficiency in young adults with Prader-Willi syndrome. Clin Endocrinol (Oxf) 79:371-378

138. Corrias A, Grugni G, Crino A, Di Candia S, Chiabotto P, Cogliardi A, Chiumello G, De Medici C, Spera S, Gargantini L et al (2012) Assessment of central adrenal insufficiency in children and adolescents with Prader-Willi syndrome. Clin Endocrinol (Oxf) 76:843-850

139. Connell NA, Paterson WF, Wallace AM, Donaldson MD (2010) Adrenal function and mortality in children and adolescents with Prader-Willi syndrome attending a single centre from 19912009. Clin Endocrinol (Oxf) 73:686-688

140. Nyunt O, Cotterill AM, Archbold SM, Wu JY, Leong GM, Verge CF, Crock PA, Ambler GR, Hofman P, Harris M (2010) Normal cortisol response on low-dose synacthen (1 microg) test in children with Prader-Willi syndrome. J Clin Endocrinol Metab 95:E464-E467

141. Farholt S, Sode-Carlsen R, Christiansen JS, Ostergaard JR, Hoybye C (2011) Normal cortisol response to high-dose synacthen and insulin tolerance test in children and adults with Prader-Willi syndrome. J Clin Endocrinol Metab 96:E173-E180

142. Blum WF, Deal C, Zimmermann AG, Shavrikova EP, Child CJ, Quigley CA, Drop SL, Cutler GB Jr, Rosenfeld RG (2013) Development of additional pituitary hormone deficiencies in pediatric patients originally diagnosed with idiopathic isolated GH deficiency. Eur J Endocrinol 170:13-21

143. Melmet S, Jameson JL (2013) Disorders of the anterior pituitary and hypothalamus. In: Jameson JL (ed) Harrison's Endocrinology, 3rd edn. McGraw-Hill, New York, pp 16-49

144. Vaitukaitis JL, Dale SL, Melby JC (1969) Role of ACTH in the secretion of dehydroepiandrosterone and its sulfate ester in man. J Clin Endocrinol Metab 29:1443-1447

145. Rosenfeld RS, Hellman L, Gallagher TF (1972) Metabolism and interconversion of dehydroepiandrosterone and dehydroepiandrosterone sulfate. J Clin Endocrinol Metab 35:187-193

146. Voutilainen R, Jääskeläinen J (2015) Premature adrenarche: etiology, clinical findings, and consequences. J Steroid Biochem Mol Biol 145:226-236 